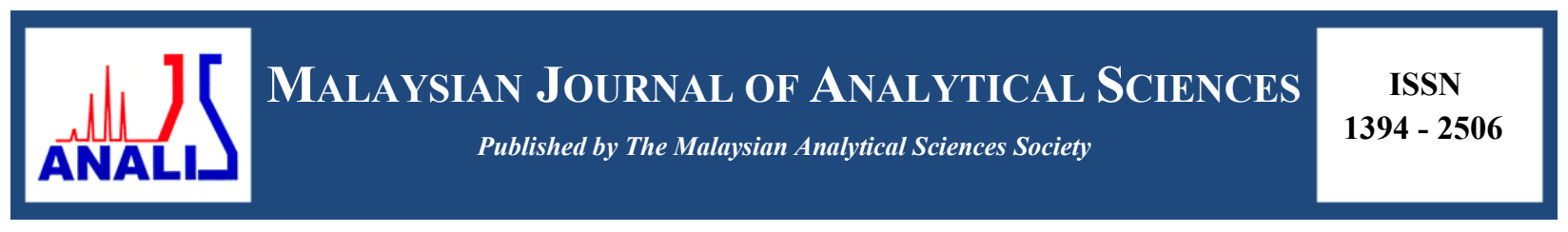

\title{
COPPER MODIFIED CARBON NITRIDE AS FLUORESCENCE SENSOR FOR NITRATE IONS
}

\author{
(Karbon Nitrida Terubah Suai Kuprum Sebagai Sensor Pendafluor Ion Nitrat) \\ Siti Maryam Jasman ${ }^{1}$, Hendrik O. Lintang ${ }^{2,3,4}$, Siew Ling Lee ${ }^{1,2}$, Leny Yuliati ${ }^{2,3,4 *}$ \\ ${ }^{l}$ Department of Chemistry, Faculty of Science \\ ${ }^{2}$ Centre for Sustainable Nanomaterials, Ibnu Sina Institute for Scientific and Industrial Research \\ Universiti Teknologi Malaysia, 81310 UTM Johor Bahru, Johor, Malaysia \\ ${ }^{3}$ Ma Chung Research Center for Photosynthetic Pigments \\ ${ }^{4}$ Department of Chemistry, Faculty of Science and Technology \\ Universitas Ma Chung, Malang 65151, East Java, Indonesia \\ *Corresponding author: leny.yuliati@machung.ac.id
}

Received: 7 November 2016; Accepted: 18 September 2017

\begin{abstract}
In this study, newly developed copper modified $\mathrm{CN}$ composites were prepared and tested as a fluorescence sensor for detection of nitrate ions $\left(\mathrm{NO}_{3}^{-}\right)$. The structure and chemical properties of $\mathrm{CN}$ and copper modified $\mathrm{CN}$ composites were investigated via $\mathrm{X}$ ray diffraction (XRD), Fourier transform infra-red (FTIR), diffuse reflectance ultraviolet-visible (DR UV-Vis) and fluorescence spectroscopies. Three emission sites represented as $\mathrm{C}=\mathrm{N}, \mathrm{C}=\mathrm{O}$ and $\mathrm{C}-\mathrm{N}$ moieties were suggested to contribute as sensing sites in

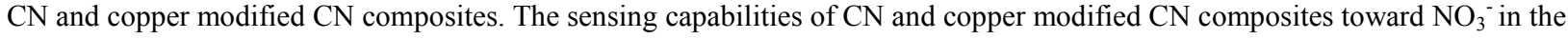
range of 300 to $1800 \mu \mathrm{M}$ were determined via a quenching technique. The quenching efficiencies $\left(K_{S V}\right)$ of $\mathrm{CN}$ and copper modified $\mathrm{CN}$ composites were obtained from the Stern-Volmer plot. Among three emission peaks of $\mathrm{CN}, \mathrm{C}=\mathrm{N}$ sites were found to be the most sensitive site having the strongest interaction with $\mathrm{NO}_{3}^{-}$. By addition of $\mathrm{Cu}(0.5 \mathrm{~mol} \%)$, the $K_{S V}$ of $\mathrm{CN}$ was improved from $2.11 \times 10^{-4}$ to $5.27 \times 10^{-4} \mu \mathrm{M}^{-1}$. This study showed that with the addition of copper as modifier, the performance of $\mathrm{CN}$ can be improved and the composite can be used as potential fluorescence sensor for the detection of $\mathrm{NO}_{3}{ }^{-}$.
\end{abstract}

Keywords: copper modified carbon nitride, fluorescence sensor, nitrate ion

\begin{abstract}
Abstrak
Dalam kajian ini, karbon nitrida terubah suai kuprum yang baru telah disediakan dan diuji sebagai sensor pendafluor untuk mengesan ion nitrat $\left(\mathrm{NO}_{3}{ }^{-}\right)$. Struktur dan sifat kimia bagi $\mathrm{CN}$ telah disiasat melalui pembelauan sinar-X (XRD), transformasian infra-merah Fourier (FTIR), spektroskopi pantulan serakan ultralembayung-cahaya nampak (DR UV-Vis) dan spektroskopi pendafluor. Tiga tapak pelepasan diwakili sebagai moiti $\mathrm{C}=\mathrm{N}, \mathrm{C}=\mathrm{O}$ dan $\mathrm{C}-\mathrm{N}$ telah dicadangkan untuk menyumbang sebagai tapak penderiaan $\mathrm{CN}$ dan komposit $\mathrm{CN}$ terubah suai kuprum. Keupayaan penderiaan $\mathrm{CN}$ dan komposit $\mathrm{CN}$ terubah suai kuprum terhadap $\mathrm{NO}_{3}{ }^{-}$dalam lingkungan 300 hingga $1800 \mu \mathrm{M}$ telah ditentukan melalui teknik pelindapan. Kecekapan pelindapan $\left(K_{S V}\right)$ bagi $\mathrm{CN}$ dan komposit $\mathrm{CN}$ terubah suai kuprum telah diperoleh daripada plot Stern-Volmer. Di antara tiga tapak pelepasan $\mathrm{CN}$, tapak $\mathrm{C}=\mathrm{N}$ telah ditemui menjadi tapak yang paling sensitif dan mempunyai interaksi paling kuat dengan $\mathrm{NO}_{3}{ }^{-}$. Dengan penambahan $\mathrm{Cu}(0.5 \mathrm{~mol} \%)$, nilai $K_{S V}$ bagi $\mathrm{CN}$ telah bertambah baik daripada $2.11 \times 10^{-4}$ kepada $5.27 \times 10^{-4} \mu \mathrm{M}^{-1}$. Kajian ini menunjukkan bahawa dengan penambahan kuprum sebagai pengubahsuai, prestasi $\mathrm{CN}$ boleh ditingkatkan dan komposit tersebut boleh digunakan sebagai potensi sensor pendafluor untuk mengesan $\mathrm{NO}_{3}{ }^{-}$.
\end{abstract}

Kata kunci: karbon nitrida terubah suai kuprum, sensor pendafluor, ion nitrat 


\section{Introduction}

Nitrate $\left(\mathrm{NO}_{3}{ }^{-}\right)$is a widespread contaminant of groundwater which can be easily detected in the environment and cause hazard to human health. The $\mathrm{NO}_{3}{ }^{-}$is largely used for food preservative, drinking water and fertilizing agents $[1,2]$. Excessive consuming of food and drinking water containing high level of $\mathrm{NO}_{3}{ }^{-}$can cause severe risk to human health especially infants. Human may metabolize $\mathrm{NO}_{3}{ }^{-}$in blood and finally transform it into carcinogenic nitrosamine causing the condition known as methemoglobinemia or also called as baby blue syndrome [3, 4]. In addition, it has been reported that the healthy human urine range of $\mathrm{NO}_{3}{ }^{-}$is in the range of 300 to $1800 \mu \mathrm{M}$ [5]. Therefore, determination of $\mathrm{NO}_{3}{ }^{-}$is an important aspect to human health and environment. Griess reagent has been used widely for detection of $\mathrm{NO}_{3}{ }^{-}$ion. Basically, Griess reaction involved several steps starting from reduction of $\mathrm{NO}_{3}{ }^{-}$to $\mathrm{NO}_{2}{ }^{-}$ion by using vanadium (III) chloride [6]. The mixture was subsequently reacted with sulfanilamide and $N$-(1-naphtyl) ethylenediamine to produce pink coloured azo dye product which strongly absorbed light at 540 $\mathrm{nm}[5,7-9]$. However, it presents several disadvantages such as using high concentration of hazardous reagent in the reaction, complicated detection procedure and cannot be reused [10]. Thus, development of reusable and sensitive sensor for detection of $\mathrm{NO}_{3}{ }^{-}$ion is highly required.

Recently, carbon nitride $(\mathrm{CN})$ has become a current interest because of its unique properties such as non-toxicity, low cost, high photoluminescence intensity [11] and good photostability [12]. CN is a graphite like layered material where $s$-triazine $\left(\mathrm{C}_{3} \mathrm{~N}_{3}\right)$ or tri-s-triazine $\left(\mathrm{C}_{6} \mathrm{~N}_{7}\right)$ units connected with amino groups $\left(-\mathrm{NH} / \mathrm{NH}_{2}\right)$ are held together through hydrogen bonds between the amino groups $[13,14]$. The principal application of the $\mathrm{CN}$ in the environment is mainly in photocatalysis for photodegradation of environmental pollutants $[15,16]$, while only few studies have been reported on its application in optical detection of environmental pollutant [17-22]. For instances, the CN has been reported to act as fluorescence sensor for detection of $\mathrm{Cu}^{2+}$ and $\mathrm{Fe}^{3+}$ ions [16-18] and $N$-Nitrosopyrrolidine [19]. Recently, metal-free $\mathrm{CN}$ was used as a fluorescence chemical sensor for detection of $\mathrm{NO}_{3}{ }^{-}$[23]. Unfortunately, $\mathrm{CN}$ alone still has low sensitivity towards the detection of the $\mathrm{NO}_{3}{ }^{-}$. Therefore, further investigation is still required to improve the performance of the $\mathrm{CN}$.

The objective of this study is to design a sensitive sensing material based $\mathrm{CN}$ by improving the sensing sites of the $\mathrm{CN}$ for detection of the $\mathrm{NO}_{3}{ }^{-}$. In order to improve the sensing sites of the $\mathrm{CN}$, copper species was used as the modifier. Copper based material has attracted a great interest due to its low cost as compared to noble metals such as $\mathrm{Au}, \mathrm{Pt}$, or Pd. It has been reported that the amino groups from the $\mathrm{CN}$ can interact with copper ion to form a stable complex due to the strong coordination force between the amino group and copper ion [24]. Herein, this study reported the modification of the $\mathrm{CN}$ by using copper species prepared by impregnation followed by a reduction method. The synthesized composites were demonstrated to show better sensing performances towards the $\mathrm{NO}_{3}{ }^{-}$.

\section{Material preparation}

\section{Materials and Methods}

$\mathrm{CN}$ was prepared by using urea $\left(\mathrm{CON}_{2} \mathrm{H}_{4}\right.$, Sigma-Aldrich, $\left.98 \%\right)$ as precursor via thermal polymerization technique at $823 \mathrm{k}$ for 4 hours $[21,25]$. As for the preparation of composites, certain amount of $\mathrm{Cu}(\mathrm{acac})_{2}\left(\mathrm{Cu}\left(\mathrm{C}_{5} \mathrm{H}_{7} \mathrm{O}_{2}\right)_{2}\right.$, Merck, 99.99\%) was dissolved in ethanol and mixed with $\mathrm{CN}$ via an impregnation process. The mixture was heated up to $363 \mathrm{~K}$ until all the ethanol was evaporated. The obtained solid was underwent thermal hydrogenation process at $473 \mathrm{~K}$ for 2 hours under hydrogen flow of $5 \mathrm{ml} / \mathrm{min}$ to produce copper species modified $\mathrm{CN}$ composites. Composites were denoted as $\mathrm{Cu}(x) / \mathrm{CN}$ composites where $x$ showed the mol ratio of $\mathrm{Cu}$ to $\mathrm{CN}$, which were fixed at 0.1 and $0.5 \mathrm{~mol} \%$. As a reference, the $\mathrm{Cu}(\mathrm{acac})_{2}$ was heated under thermal hydrogenation process at $473 \mathrm{~K}$ or 2 hours to obtain $\mathrm{Cu}$ metal.

\section{Characterizations}

Properties of $\mathrm{CN}$ and $\mathrm{Cu}(x) / \mathrm{CN}$ composites were investigated by several instruments. The structure of the $\mathrm{CN}$ and its composite was identified by using powder X-ray difractometer recorded with a Bruker D8 Advanced using $\mathrm{Cu}$ $\mathrm{K} \alpha$ irradiation $(\lambda=1.5406 \AA)$. The surface area of $\mathrm{CN}$ and its composites was confirmed by using BrunauerEmmett-Teller (BET) equation obtained from a Quantachrome NOVA TOUCH LX ${ }^{4}$. The functional groups present in the $\mathrm{CN}$ and its composites were recorded by using a Nicolet iS50 spectroscopy by mixing the samples with potassium bromide as a pellet. The diffuse reflectance UV-Visible (DR UV-Vis) spectra were recorded by using 
Shimadzu UV-Vis spectrophotometry (UV-2600) in the range of $250-800 \mathrm{~nm}$. The emission spectra were determined via JASCO FP-8500 fluorescence spectrophotometer at room temperature.

\section{Quenching test}

The interactions between the $\mathrm{CN}$ and its composites with $\mathrm{NO}_{3}{ }^{-}$were studied via fluorescence spectroscopy at room temperature. The quenching tests were carried out by exposing various concentrations of $\mathrm{NO}_{3}{ }^{-}$in the range of 300 to $1800 \mu \mathrm{M}$ onto the $\mathrm{CN}$ and its composites. The various concentrations of $\mathrm{NO}_{3}{ }^{-}(10 \mu \mathrm{L})$ were introduced into the sample $(0.05 \mathrm{~g})$ and the emission spectra were measured at excitation wavelengths of 277,320 and $370 \mathrm{~nm}$. The interaction between the samples and the $\mathrm{NO}_{3}{ }^{-}$can be observed from the changes in the emission intensity measured at each excitation wavelength and evaluated from the Stern-Volmer plot.

\section{Characterization of $\mathrm{CN}$ and $\mathrm{Cu}(\mathrm{x}) / \mathrm{CN}$ composites}

\section{Results and Discussion}

To investigate the chemical structure and optical properties of CN and its composites, XRD, FTIR, DR UV-Vis and fluorescence spectroscopies measurements were performed. The XRD patterns of $\mathrm{CN}$ and its composites are given in Figure 1. The XRD pattern of the prepared $\mathrm{Cu}$ metal is also shown as a reference. $\mathrm{Cu}$ metal gave three obvious peaks at $2 \theta$ of $44.3,50.4$ and $74.1^{\circ}$ as the characteristics of copper (0) species (JCPDS no. 00-004-0836), which pattern was virtually the same as the reported one [26]. On the other hand, the $\mathrm{CN}$ exhibited two diffraction peaks at $2 \theta$ of 13.10 and $27.30^{\circ}$, corresponding to in-planar repeating units and the distance between the nitride pores, respectively $[20,23,27-30]$. The $\mathrm{Cu}(x) / \mathrm{CN}$ composites showed similar diffraction patterns to those of the $\mathrm{CN}$, suggesting that the added $\mathrm{Cu}$ might be too low to be detected by XRD or the $\mathrm{Cu}$ was highly dispersed on the $\mathrm{CN}$.

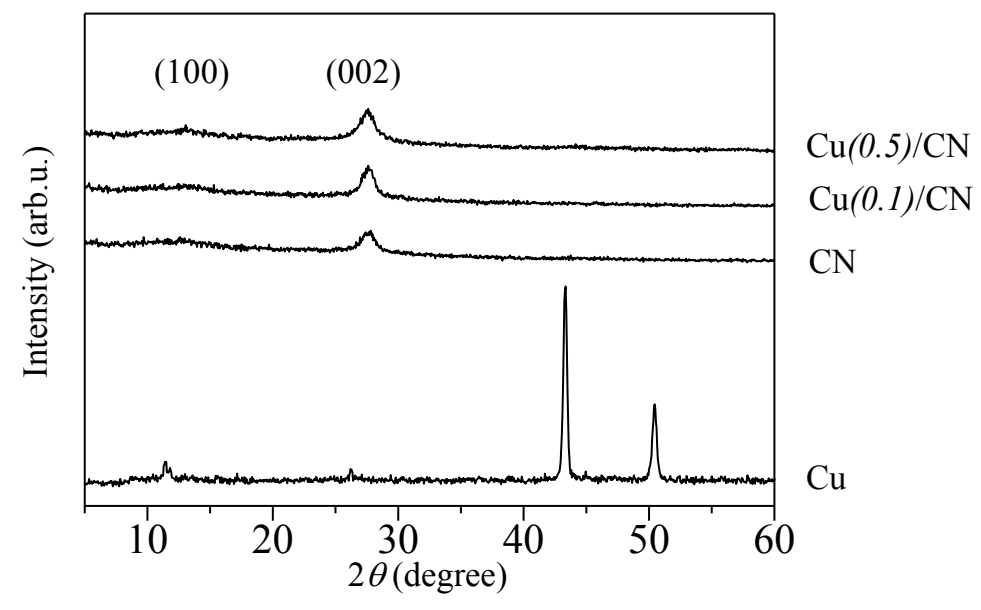

Figure 1. XRD patterns of $\mathrm{Cu}, \mathrm{CN}$ and $\mathrm{Cu}(x) / \mathrm{CN}$ composites

The FTIR spectra of $\mathrm{CN}$ and the $\mathrm{Cu}(x) / \mathrm{CN}$ composites are shown in Figure 2. The $\mathrm{CN}$ showed vibration bands at around $3300-3400 \mathrm{~cm}^{-1}$ that can be attributed to the overlapping bands of primary and secondary amine, $v(\mathrm{~N}-\mathrm{H})$ and $v(\mathrm{O}-\mathrm{H})$ groups $[21-24,31-35]$. The stretching modes of $v(\mathrm{C}-\mathrm{N})$ heterocycles were observed at $1200-1700 \mathrm{~cm}^{-1}$, while the heterocyclic tri-s-triazine $\left(\mathrm{C}_{6} \mathrm{~N}_{7}\right)$ was found at around $809 \mathrm{~cm}^{-1}$. Even though the presence of amino groups in the synthesized CN is difficult to be analysed by FTIR spectroscopy, it has been reported by XPS analysis [31]. It was obvious that the $\mathrm{Cu}(x) / \mathrm{CN}$ composite exhibited almost similar peaks to those of the $\mathrm{CN}$, which indicated that the structure of $\mathrm{CN}$ was kept to be almost the same even after addition of copper species on the samples, similar to other reported literatures [24, 32]. 


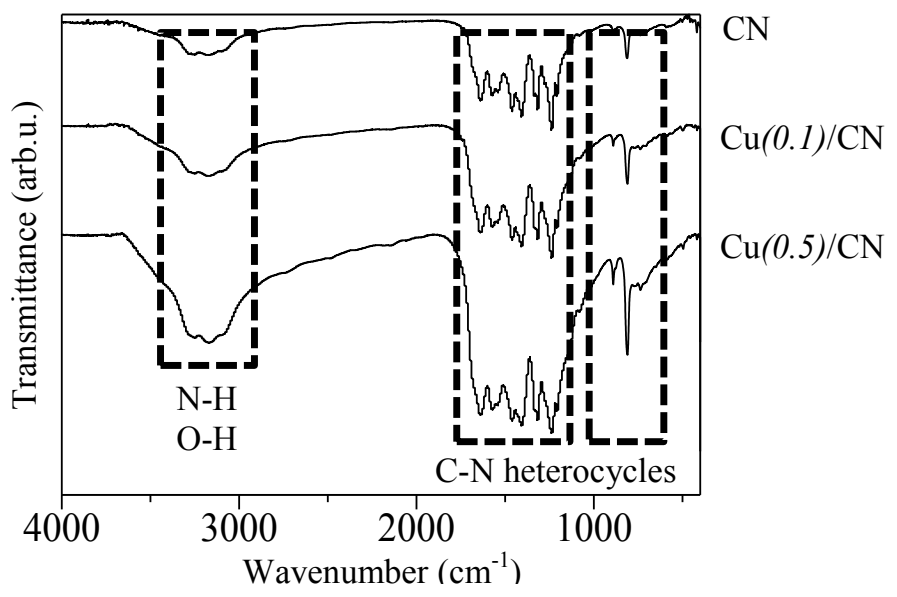

Figure 2. FTIR spectra of $\mathrm{CN}$ and $\mathrm{Cu}(x) / \mathrm{CN}$ composites

Figure 3 shows $\mathrm{N}_{2}$ adsorption-desorption isotherms of $\mathrm{CN}$ and its composites. It was obvious that they exhibited type III isotherm, which referred to nonporous solids. There were no change occurred on the isotherm when the $\mathrm{Cu}$ species were added onto the samples, suggesting that the added copper species did not affect the physical properties of the $\mathrm{CN}$. The BET specific surface areas of $\mathrm{CN}, \mathrm{Cu}(0.1) / \mathrm{CN}$, and $\mathrm{Cu}(0.5) / \mathrm{CN}$ were measured to be 91,93 and 56 $\mathrm{m}^{2} \mathrm{~g}^{-1}$, respectively. Addition of $0.1 \mathrm{~mol} \%$ of $\mathrm{Cu}$ did not affect much the specific surface area, but the addition of 0.5 mol\% of $\mathrm{Cu}$ significantly decreased the specific surface area. The decrease in the surface area has been also reported when $\mathrm{Cu}(\mathrm{acac})_{2}$ was dispersed on the $\mathrm{CN}$ [32].
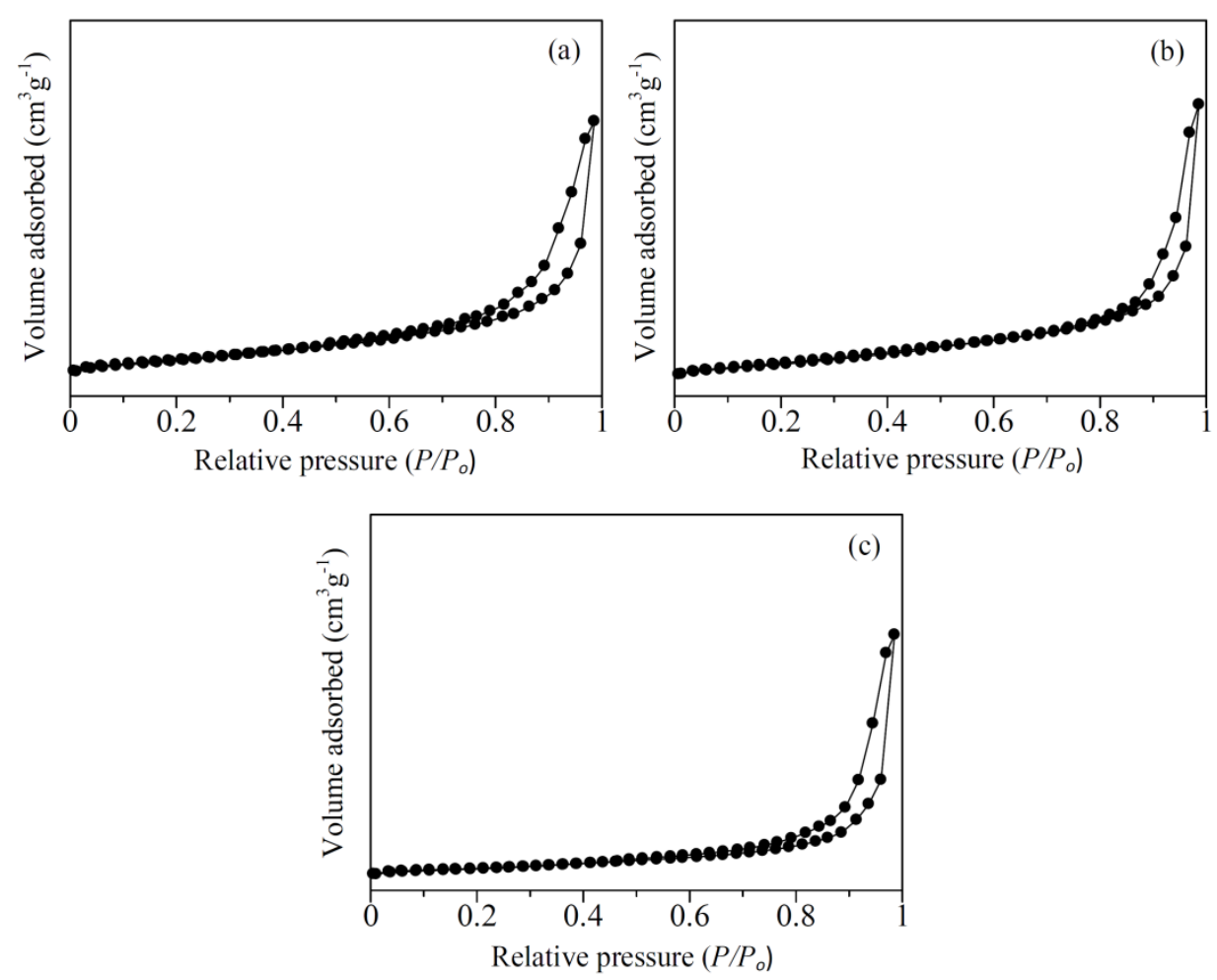

Figure 3. $\mathrm{N}_{2}$ adsorption-desorption of (a) $\mathrm{CN}$, (b) $\mathrm{Cu}(0.1) / \mathrm{CN}$ and (c) $\mathrm{Cu}(0.5) / \mathrm{CN}$ composites 


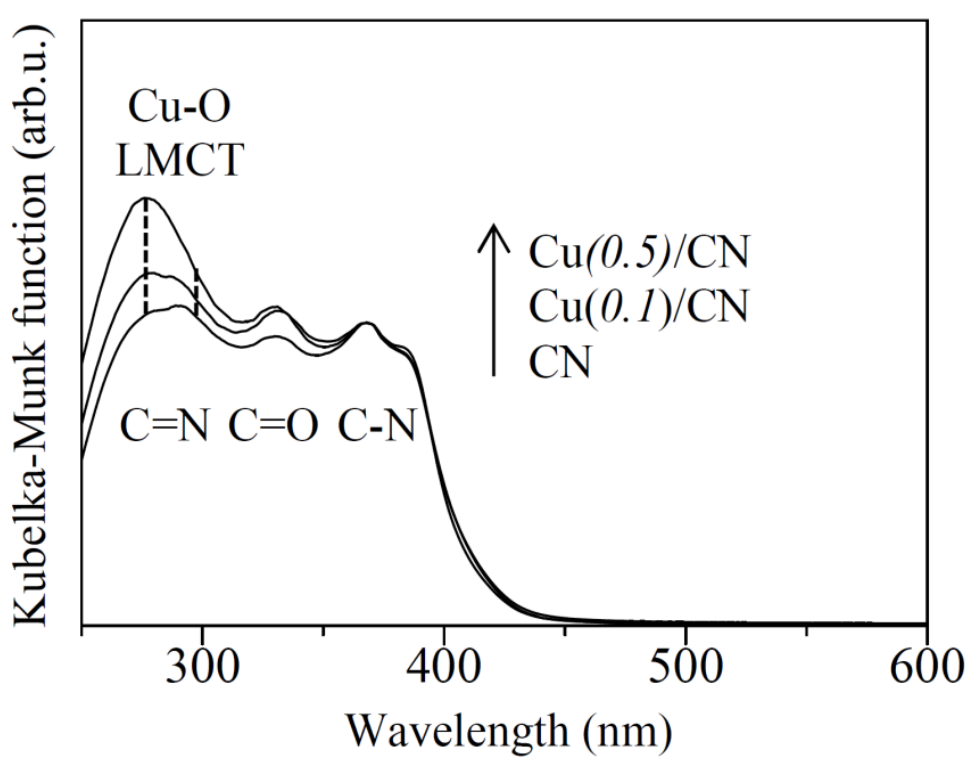

Figure 4. DR UV-Vis spectra of $\mathrm{CN}$ and $\mathrm{Cu}(x) / \mathrm{CN}$ composites

The optical properties of $\mathrm{CN}$ and its composites were investigated by DR UV-Vis spectroscopy. As shown in Figure $4, \mathrm{CN}$ and its composites exhibited three strong absorption bands at 277, 320 and $370 \mathrm{~nm}$. The peak at $277 \mathrm{~nm}$ was corresponded to $\mathrm{C}=\mathrm{N}$ groups $\left(\pi-\pi^{*}\right)$ in the conjugated aromatic triazine ring $[20,23,31,32]$, while the peak at 320 $\mathrm{nm}$ would be related to the presence of $\mathrm{C}=\mathrm{O}$ moiety $\left(\pi-\pi^{*}\right.$ and $\left.n-\pi^{*}\right)$ due to the low condensation during the polymerization process of urea $[30,32,36]$. The peak at $370 \mathrm{~nm}$ was originated from the C-N terminal moiety $(n$ $\left.\pi^{*}\right)[20,23,31,32]$. The $\mathrm{Cu}(x) / \mathrm{CN}$ composites also gave similar absorption peaks to the $\mathrm{CN}$, but with increased absorption peak intensities below $350 \mathrm{~nm}$. The increase was more prominent for $\mathrm{Cu}(x) / \mathrm{CN}$ composite with higher $\mathrm{Cu}$ loading amount. This would be the evidence of the presence of $\mathrm{Cu}$ on the samples since the peaks were contributed from the ligand to metal charge transfer (LMCT) transition between $\mathrm{Cu}$ and oxygen species in the composites [37].

The fluorescence properties of $\mathrm{CN}$ and $\mathrm{Cu}(x) / \mathrm{CN}$ composites were studied by using fluorescence spectroscopy. Similar to the DR UV-Vis spectra, CN and its composites also shows three excitation peaks at 277,320 and $370 \mathrm{~nm}$, which referred to $\mathrm{C}=\mathrm{N}, \mathrm{C}=\mathrm{O}$ and $\mathrm{C}-\mathrm{N}$ terminal groups, respectively. On the other hand, only one emission peak was observed when $\mathrm{CN}$ and its composites were excited at 277, 320 or $370 \mathrm{~nm}$ [23]. As can be seen in Figure 5 (a), the intensity of the excitation spectra of the composites decreased with the increase in the loading amount of $\mathrm{Cu}$ species. This is believed due to certain interactions occurred between $\mathrm{Cu}$ species and $\mathrm{CN}$. The same phenomenon also can be monitored from the emission spectra of $\mathrm{CN}$ and its composites at $455 \mathrm{~nm}$ for all excitation wavelengths, as can be seen in Figure 5 (b), (c) and (d), which illustrates the emission spectra of CN and its composites when excited at 277,320 and $370 \mathrm{~nm}$, respectively. 

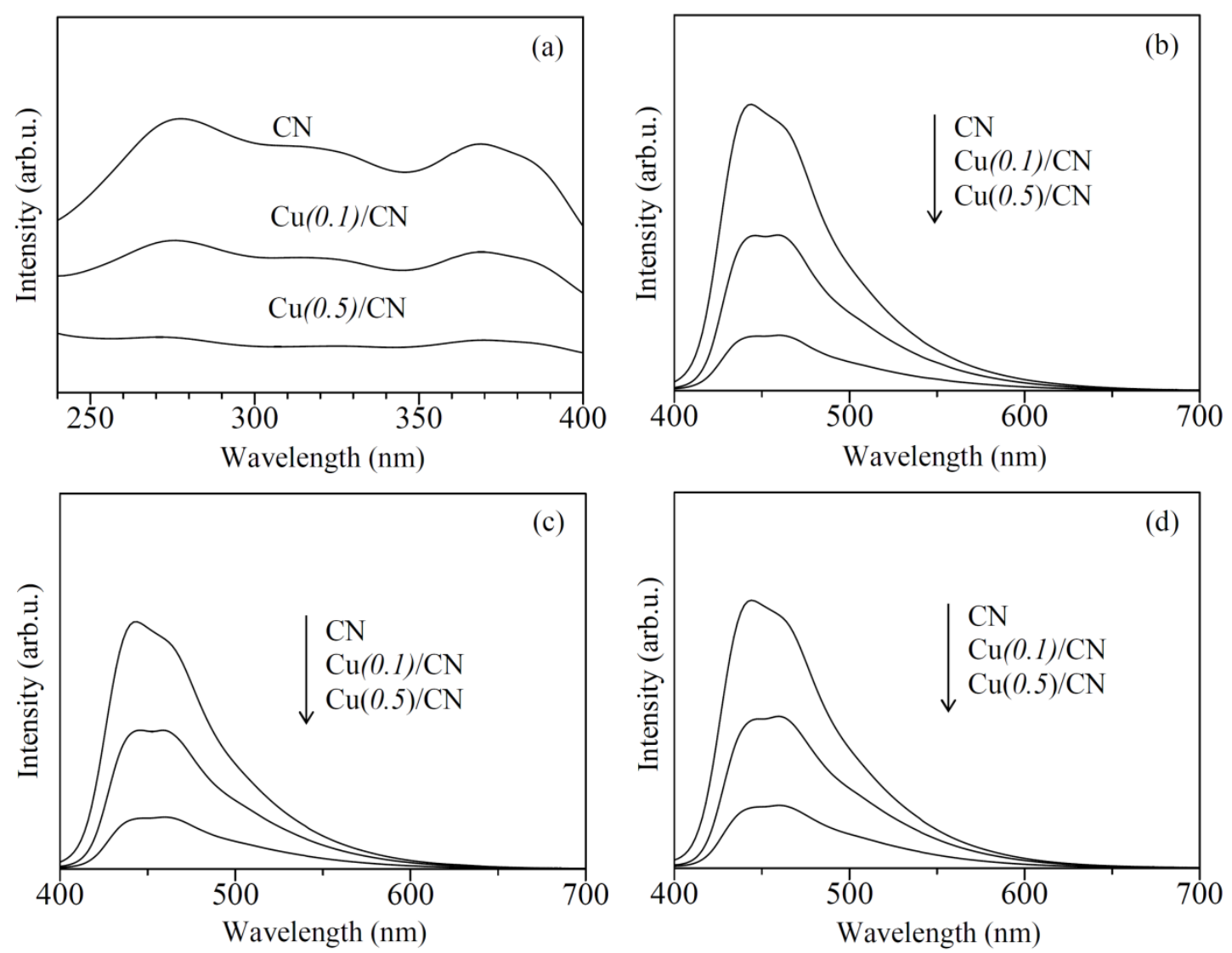

Figure 5. (a) Excitation spectra of $\mathrm{CN}$ and $\mathrm{Cu}(x) / \mathrm{CN}$ composites monitored at emission wavelength of $455 \mathrm{~nm}$, and emission spectra of $\mathrm{CN}$ and $\mathrm{Cu}(x) / \mathrm{CN}$ composites monitored at excitation wavelengths of (b) 277, (c) 320 and (e) $370 \mathrm{~nm}$

\section{Sensing performance of $\mathrm{CN}$ and $\mathrm{Cu}(x) / \mathrm{CN}$ composites toward $\mathrm{NO}_{3}{ }^{-}$ion}

The fluorescence responses of $\mathrm{CN}$ and its composites to various concentrations of $\mathrm{NO}_{3}^{-}(300-1800 \mu \mathrm{M})$ were studied by using a quenching technique. Since the $\mathrm{CN}$ and its composites have three emission sites, which are $\mathrm{C}=\mathrm{N}$, $\mathrm{C}=\mathrm{O}$ and $\mathrm{C}-\mathrm{N}$ terminal groups, it is important to determine which emission site has the strongest interaction to $\mathrm{NO}_{3}{ }^{-}$. Figure 6 shows the emission spectra of $\mathrm{CN}$ at 277, 320 and $370 \mathrm{~nm}$ before and after addition of various concentrations of $\mathrm{NO}_{3}$. Based on the spectra, it is clearly seen that the intensity of $\mathrm{CN}$ decreased with the increase of the $\mathrm{NO}_{3}{ }^{-}$concentration at all sensing sites, suggesting that the $\mathrm{NO}_{3}{ }^{-}$ion interacted with $\mathrm{C}=\mathrm{N}, \mathrm{C}=\mathrm{O}$ and $\mathrm{C}-\mathrm{N}$ terminal sites and acted as a quenching agent to deactivate the emission sites of the $\mathrm{CN}$. It is believed that there is an electrostatic interaction between the $\mathrm{CN}$ and its composites with $\mathrm{NO}_{3}{ }^{-}$due to different charge between the sensing sites of the sensor samples and the $\mathrm{NO}_{3}{ }^{-}$[38]. The same phenomena also can be observed for $\mathrm{Cu}(0.1) / \mathrm{CN}$ and $\mathrm{Cu}(0.5) / \mathrm{CN}$ samples, which spectra are shown in Figures 7 and 8, respectively. 

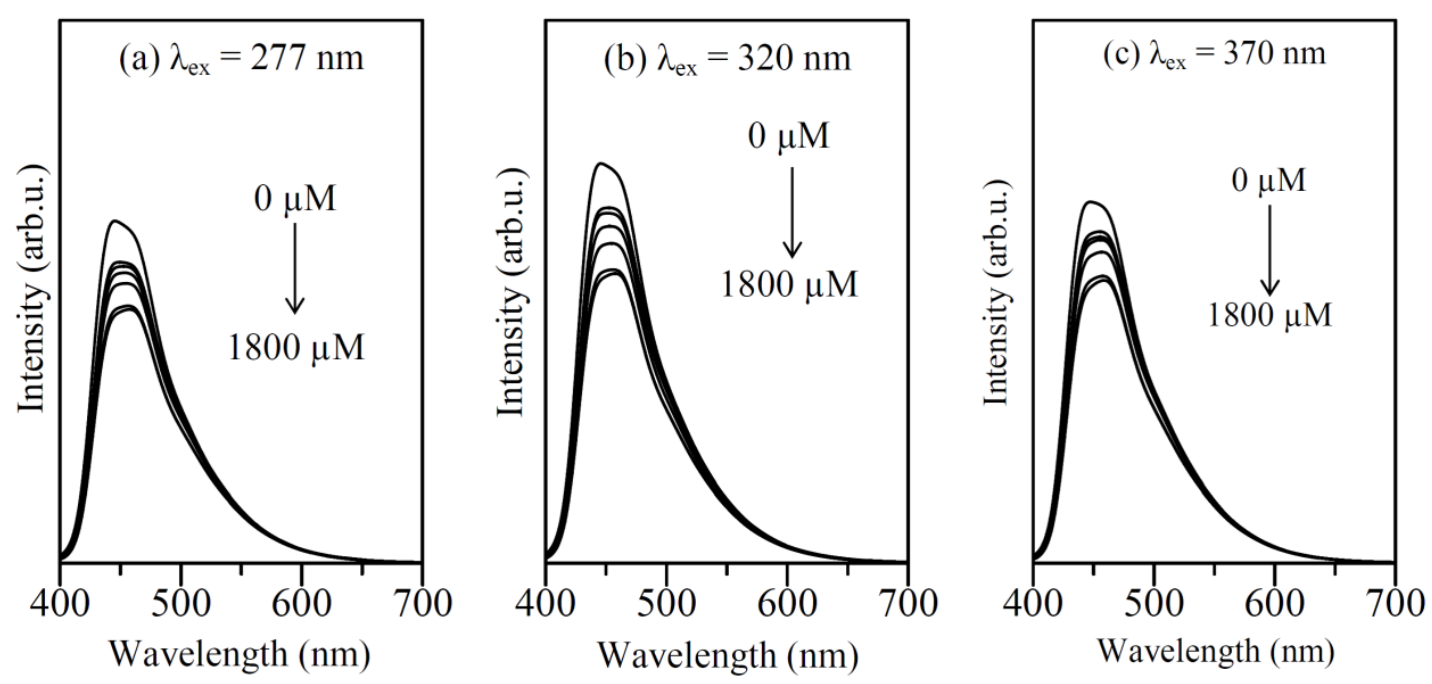

Figure 6. Emission spectra of $\mathrm{CN}$ in the absence and presence of $\mathrm{NO}_{3}{ }^{-}$with various concentrations, monitored at excitation wavelength of (a) 277, (b) 320 and (c) $370 \mathrm{~nm}$
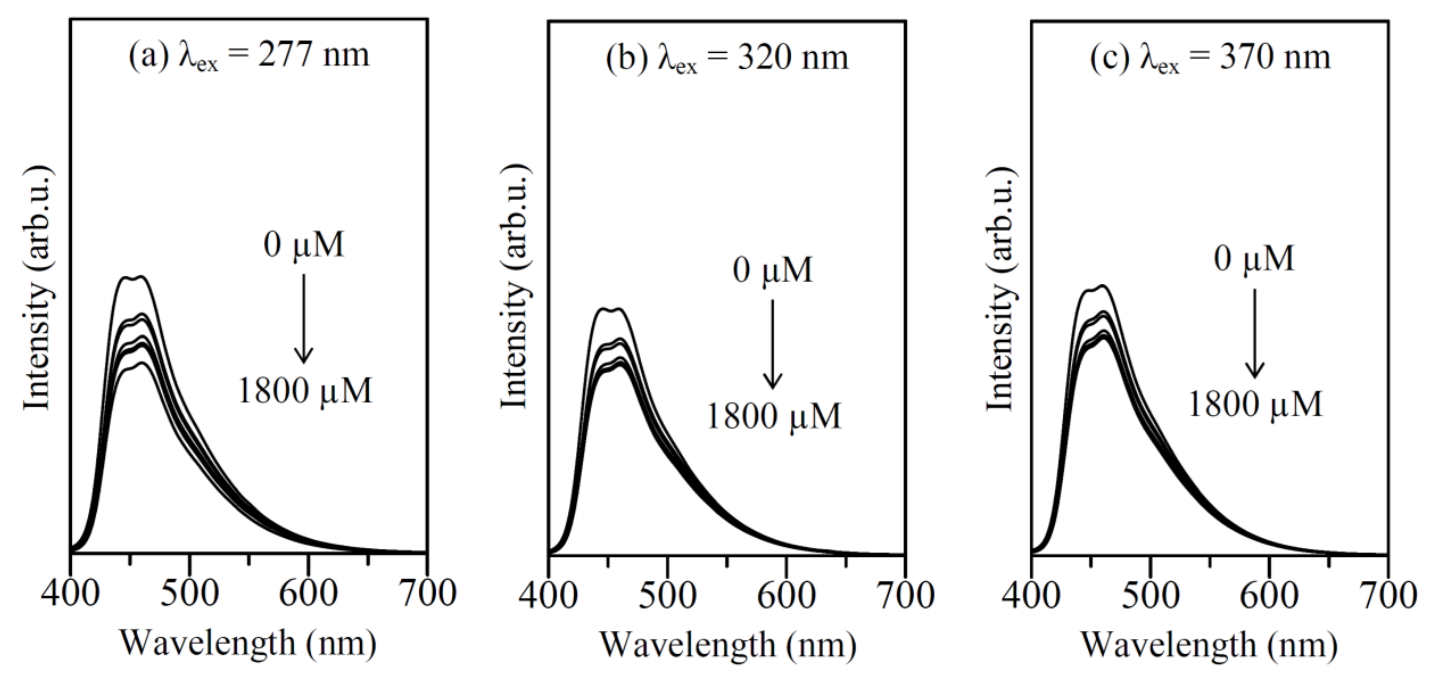

Figure 7. Emission spectra of $\mathrm{Cu}(0.1) / \mathrm{CN}$ in the absence and presence of $\mathrm{NO}_{3}{ }^{-}$with various concentrations, monitored at excitation wavelength of (a) 277, (b) 320 and (c) $370 \mathrm{~nm}$ 

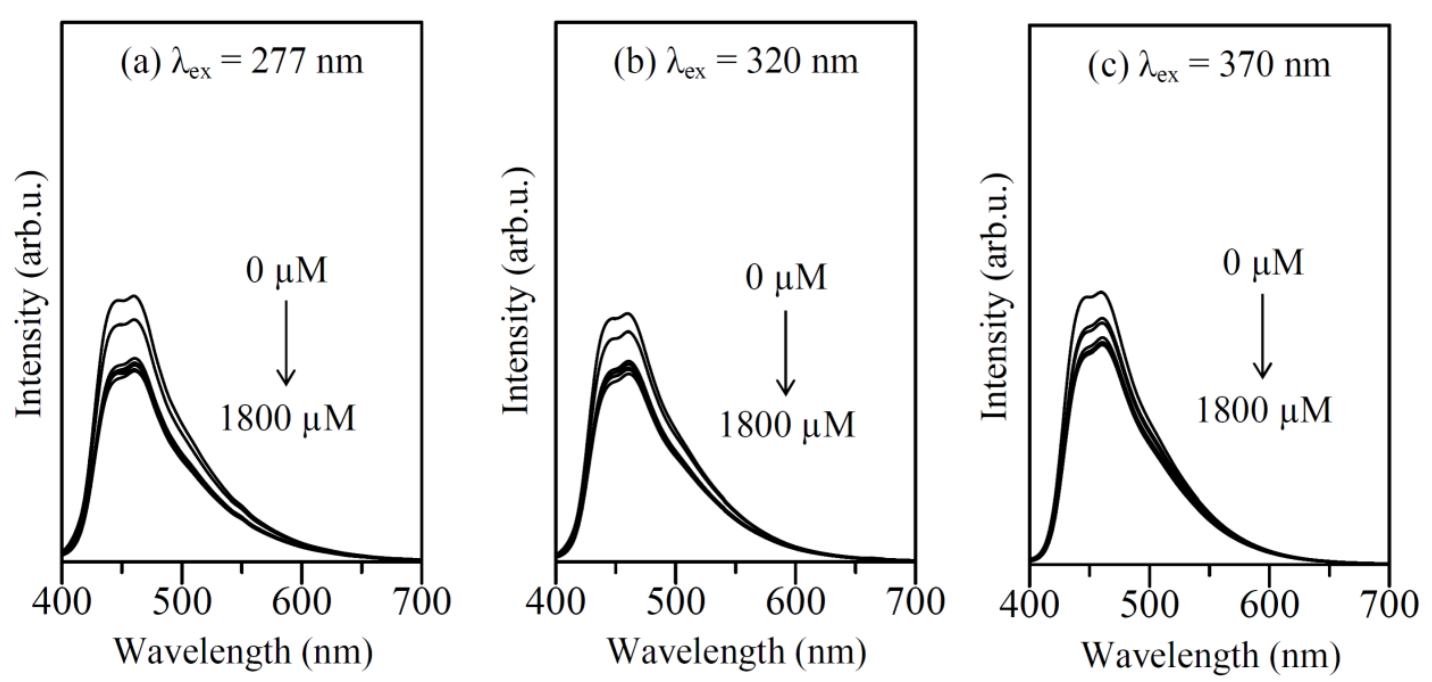

Figure 8. Emission spectra of $\mathrm{Cu}(0.5) / \mathrm{CN}$ in the absence and presence of $\mathrm{NO}_{3}^{-}$with various concentrations, monitored at excitation wavelength of (a) 277 , (b) 320 and (c) $370 \mathrm{~nm}$

In order to determine the most sensitive sensing sites on the $\mathrm{CN}$ and its composites, quenching efficiencies at each sensing sites of the samples need to be calculated. The quenching efficiencies of the sensor can be determined by the relationship between the reduced intensity and the added concentration of $\mathrm{NO}_{3}^{-}$, which is reflected by the SternVolmer equation:

$$
I_{0} / I=K_{S V}[Q]+1
$$

where $I_{0}$ is the fluorescence intensity of sensor in the absence of quencher $\left(\mathrm{NO}_{3}{ }^{-}\right)$and $I$ is the fluorescence intensity of sensor in the presence of quencher $\left(\mathrm{NO}_{3}{ }^{-}\right), K_{S V}$ is the Stern-Volmer constant which measures the efficiency of quenching and $[Q]$ is the concentration of $\mathrm{NO}_{3}{ }^{-}$.

Among the three sensing sites of the $\mathrm{CN}$ and its composites, which are $\mathrm{C}=\mathrm{N}, \mathrm{C}=\mathrm{O}$ and $\mathrm{C}-\mathrm{N}$ terminal groups, the $\mathrm{C}=\mathrm{N}$ showed the strongest interaction between the samples and the $\mathrm{NO}_{3}{ }^{-}$ion. The Stern-Volmer plots of the $\mathrm{CN}$ and $\mathrm{Cu}(x) / \mathrm{CN}$ composites for the $\mathrm{C}=\mathrm{N}$ sites monitored at excitation wavelength of $277 \mathrm{~nm}$ are shown in Figure 9. The $\mathrm{CN}$ gave almost linear plot to sense $\mathrm{NO}_{3}{ }^{-}$ion up to $1800 \mu \mathrm{M}$. On the other hand, the $\mathrm{Cu}(0.1) / \mathrm{CN}$ composite and the $\mathrm{Cu}(0.5) / \mathrm{CN}$ composites gave a linear plot up to 1500 and $900 \mu \mathrm{M}$, respectively. When the added concentration was higher than these concentration levels, saturation was observed and this was more prominently observed on the $\mathrm{Cu}(0.5) / \mathrm{CN}$. The addition of $\mathrm{Cu}$ was found to give lower concentration range detection, which may be caused by the blocking of the sensing sites by the added $\mathrm{Cu}$ species. However, it is clear that the addition of $\mathrm{Cu}$ improved the quenching efficiency of the $\mathrm{CN}$. The calculated $K_{S V}$ values of $\mathrm{CN}, \mathrm{Cu}(0.1) / \mathrm{CN}$ and $\mathrm{Cu}(0.5) / \mathrm{CN}$ composites at excitation wavelength of $277 \mathrm{~nm}$ were $2.11 \times 10^{-4}, 2.50 \times 10^{-4}$ and $5.27 \times 10^{-4} \mu \mathrm{M}^{-1}$, respectively, as summarized in Figure 10. Although detection range on the $\mathrm{Cu}(0.5) / \mathrm{CN}$ composite was lower, obviously the $\mathrm{Cu}(0.5) / \mathrm{CN}$ composite showed almost twofold higher $K_{S V}$ value as compared to the unmodified CN. It is revealed that the presence of copper species improved the performance of $\mathrm{CN}$ for the detection of $\mathrm{NO}_{3}{ }^{-}$ion. Therefore, it can be concluded that $\mathrm{Cu}(x) / \mathrm{CN}$ composites were potential to be used as a fluorescence sensor for detection of $\mathrm{NO}_{3}{ }^{-}$ion. 


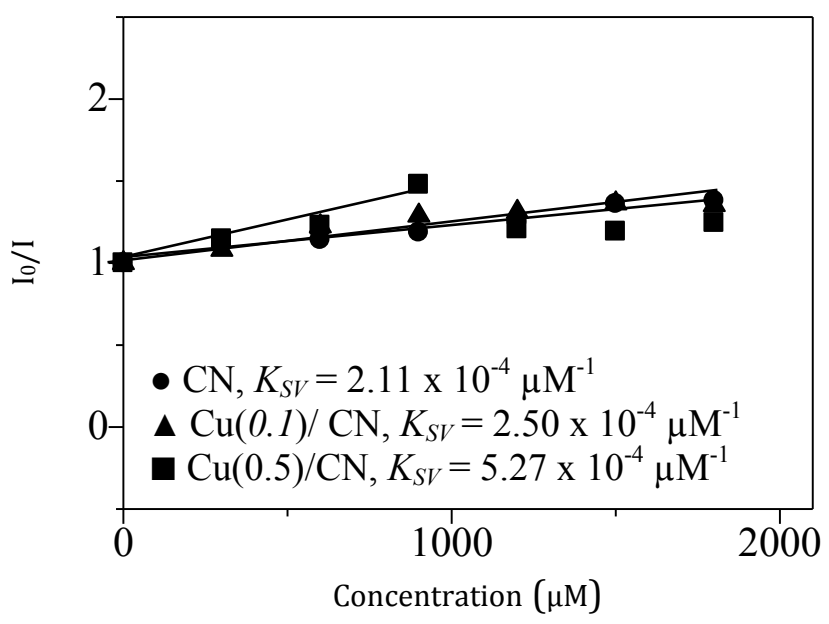

Figure 9. Stern-Volmer plots between the relative emission intensity of $\mathrm{CN}$ and $\mathrm{Cu}(x) / \mathrm{CN}$ and the concentration of $\mathrm{NO}_{3}{ }^{-}$, monitored at excitation wavelength of $\mathrm{C}=\mathrm{N}$ sites $(277 \mathrm{~nm})$

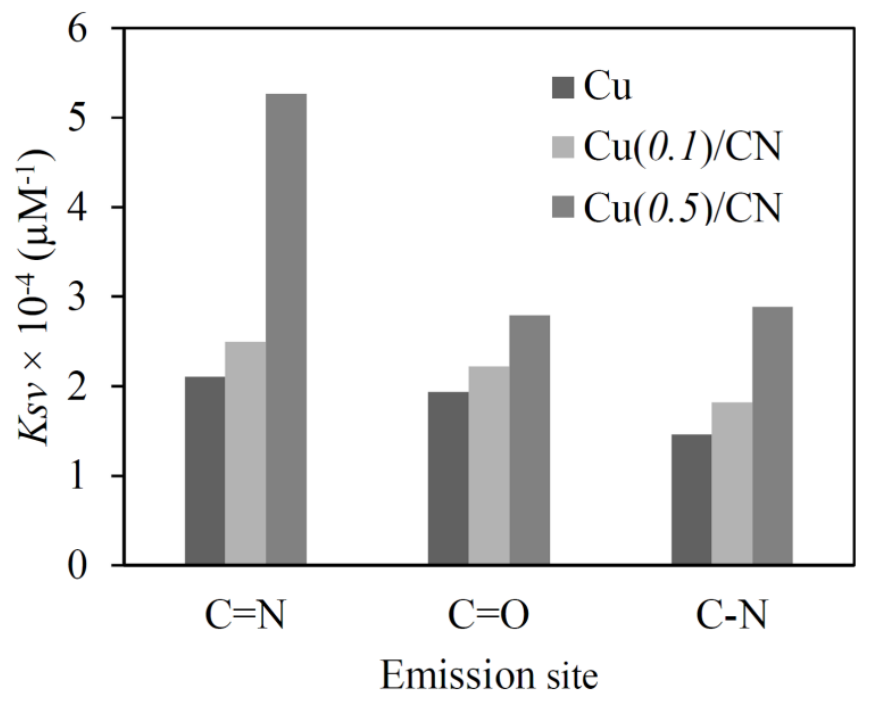

Figure 10. The $\mathrm{K}_{\mathrm{Sv}}$ values for $\mathrm{CN}$ and $\mathrm{Cu}(x) / \mathrm{CN}$ for all the emission sites

\section{Conclusion}

The $\mathrm{CN}$ was successfully synthesized via a thermal polymerization technique, while the $\mathrm{Cu}(x) / \mathrm{CN}$ composites were prepared by impregnation of copper species, followed by thermal reduction process. XRD patterns and FTIR spectra did not show any changes, suggesting that the structural properties of $\mathrm{CN}$ were not influenced by the addition of copper species onto CN. On the other hand, the DR UV-Vis spectra showed the presence of copper species in the composites in the area below $350 \mathrm{~nm}$, which was due to the LMCT between the copper species and $\mathrm{CN}$. The CN and $\mathrm{Cu}(x) / \mathrm{CN}$ composites exhibited three emission sites, which are $\mathrm{C}=\mathrm{N}, \mathrm{C}=\mathrm{O}$ and $\mathrm{C}-\mathrm{N}$ sites. Among all these emission sites, the $\mathrm{C}=\mathrm{N}$ site showed the most favorable sensing site for detection of $\mathrm{NO}_{3}{ }^{-}$ion. The quenching efficiencies were represented by the $K_{S V}$ values, which values for $\mathrm{CN}, \mathrm{Cu}(0.1) / \mathrm{CN}$ and $\mathrm{Cu}(0.5) / \mathrm{CN}$ composites were $2.11 \times 10^{-4}, 2.50 \times 10^{-4}$ and $5.27 \times 10^{-4} \mu \mathrm{M}^{-1}$, respectively. Modification with copper species $(0.5 \mathrm{~mol} \%)$ onto the $\mathrm{CN}$ improved the quenching efficiency up to two times higher than the unmodified $\mathrm{CN}$. This work clearly demonstrated that the $\mathrm{Cu}(x) / \mathrm{CN}$ composites can be used as a potential fluorescence sensor for detection of $\mathrm{NO}_{3}{ }^{-}$ion. 


\section{Acknowledgements}

This work was financially supported by the Ministry of Higher Education (MOHE, Malaysia) and the Universiti Teknologi Malaysia (UTM, Malaysia) through the Research University Grant (Tier-1, cost center code: Q.J130000.2526.10H74). S.M.J also acknowledges financial support from MyBrain15 Scholarship.

\section{References}

1. Aravamudhan, S. and Bhansali, S. (2008). Development of micro-fluidic nitrate-selective sensor based on doped-polypyrrole nanowires. Sensors and Actuators B, 132: 623 - 630 .

2. Guadagnini, L. and Tonelli, D. (2008). Carbon electrodes unmodified and decorated with silver nanoparticles for the determination of nitrite, nitrate and iodate. Sensors and Actuators B, 188: 806 -814.

3. Ogata, F., Imai, D. and Kawasaki, N. (2015). Adsorption of nitrate and nitrite ions onto carbonaceous material produced from soybean in binary solution system. Journal of Environmental Chemical Engineering, 3: 155 161.

4. Kim, D., Goldberg, I. B. and Judy, J. W. (2009). Microfabricated electrochemical nitrate sensor using doublepotential-step chronocoulometry. Sensor and Actuators B, 135: 618 - 624 .

5. Trikas, D. (2007). Analysis of nitrite and nitrate in biological fluids by assays based on the Griess Reaction: Appraisal of the Griess Reaction in the L-arginine/nitric oxide area of research. Journal of Chromatography B, 851: $51-70$.

6. Wang, S., Lin, K., Chen, N., Yuan, D. and Ma, J. (2016). Automated determination of nitrate plus nitrite in aqueous samples with flow injection analysis using vanadium (III) chloride as reductant. Talanta, 146: 744 748.

7. Lee, M., Lee, Y., Soltermann, F. and Gunten, U. V. (2013). Analysis of $N$-nitrosamines and other nitro(so) compounds in water by high-performance liquid chromatography with post-column UV photolysis/Griess reaction. Water Research, 47: 4893 - 4903.

8. Ridnour, L. A., Sim, J. E., Hayward, M. A., Wink, D. A., Martin, S. M., Buettner, G. R. and Spitz. D. R. (2000). A spectrophotometric method for the direct detection and quantification of nitric oxide, nitrite and nitrate in cell culture media. Analytical Biochemistry, 281: 223 - 229.

9. Bryan, N. S. and Grisham. M. B. (2007). Methods to detect nitric oxide and its metabolites in biological samples. Free Radical Biology and Medicine, 43(5): 645 - 657.

10. Kumar, V. V. and Anthony, S. P. (2014). Highly selective silver nanoparticles based label free colorimetric sensor for nitrite anions. Analytica Chimica Acta, 842: 57 - 62 .

11. Hernandez-Torres, J., Gutierrez-Franco, A., Gonzalez, P. G., Garcia-Gonzalez, L., Hernandez-Quiroz, T., Zamora-Peredo, L., Mendez-Garcia, V. H. and Cisneros-de la Rosa. A. (2016). Photoluminescence and raman spectroscopy studies of carbon nitride films. Journal of Spectroscopy, 2016: 1 - 8 .

12. Chai, B., Peng, T., Mao, J., Li, K. and Zan, L. (2012). Graphitic carbon nitride $\left(\mathrm{g}_{-} \mathrm{C}_{3} \mathrm{~N}_{4}\right)-\mathrm{Pt}-\mathrm{TiO}_{2}$ nanocomposite as an efficient photocatalyst for hydrogen production under visible light irradiation. Physical Chemistry Chemical Physics, 14: 16745 - 16752.

13. Yang, S., Gong, Y., Zhang, J., Zhan, L., Ma, L., Fang, Z., Vajtai, R., Wang, X. and Ajayan, P. M. (2013). Exfoliated graphitic carbon nitride nanosheets as efficient catalyst for hydrogen evolution under visible light. Advanced Material, 25: $2452-2456$.

14. Thomas, A. Fischer, A. Goettmann, F. Antonietti, M. Muler, J-O. Schlogl, R. and Carlsson, J. M. (2008). Graphitic carbon nitride materials: Variation of structure and morphology and their use as metal-free catalysts. Journal of Material Chemistry, 18: 4893 - 4908.

15. Xia, B., Chu, M., Wang, S, Wang, W., Yang, S., Liu, C. and Luo, S. (2015). Graphene oxide amplified electrochemiluminescence of graphitic carbon nitride and its application in ultrasensitive sensing for $\mathrm{Cu}^{2+}$. Analytical Chemica Acta, 9: 891:113 - 119.

16. Zhao, Z., Sun, Y. and Dong, F. (2015). Graphitic carbon nitride based nanocomposites: A review. Nanoscale, 7: $15-37$.

17. Lee, E. Z., Jun, Y-S., Hong, W. H., Thomas, A. and Jin, M. M. (2010). Cubic mesoporous graphitic carbon(iv) nitride: an all-in-one chemosensor for selective optical sensing of metal ions. Angewandte Chemie International Edition, 49: 9706 - 9710. 
18. Tian, J., Liu, Q., Asiri, A. M., Al-Youbi, A. O. and Sun, X. (2013). Ultrathin graphitic carbon nitride nanosheet: A highly efficient fluorosensor for rapid, ultrasensitive detection of $\mathrm{Cu}^{2+}$. Analytical Chemistry, 85: $5595-5599$.

19. Zhang, S., Li, J., Zeng, M., Xu, J., Wang, X. and Hu, W. (2014). Polymer nanodots of graphitic carbon nitride as effective fluorescent probes for the detection of $\mathrm{Fe}^{3+}$ and $\mathrm{Cu}^{2+}$ Ions. Nanoscale, 6: $4157-4162$.

20. Sam, M. S., Lintang, H. O., Sanagi, M. M., Lee, S. L. and Yuliati, L. (2014). Mesoporous carbon nitride for adsorption and fluorescence sensor of $n$-nitrosopyrrolidine. Spectrochimica Acta Part A: Molecular and Biomolecular Spectroscopy, 124: 357 - 364.

21. Mane, G. P. Dhawale, D. S. Anand, C. Ariga, K. Ji, Q. Wahab, M. A. Mori, T. and Vinu, A. (2013). Selective sensing performance of mesoporous carbon nitride with a highly ordered porous structure prepared from 3 amino-1,2,4-triazine. Journal of Materials Chemistry A, 1: 2913 - 2920.

22. Wang, Q., Wang, W., Lei, J., Xu, N., Gaul, F. and Ju, H. (2013). Fluorescence quenching of carbon nitride nanosheet through its interaction with DNA for versatile fluorescence sensing. Analytical Chemistry. 85: 12182 -12188 .

23. Alim, N. S. Lintang, H. O. and Yuliati, L. (2015). Fabricated metal-free carbon nitride characterizations for fluorescence chemical sensor of nitrate ions. Journal Teknologi, 76(13): $1-6$.

24. Wang, N., Han, Z., Fan, H. and Ai, S. (2015). Copper nanoparticles modified graphitic carbon nitride nanosheets as a peroxidase mimetic for glucose detection. RSC Advances, 5: 91302 - 91307.

25. Lee, S. C., Lintang, H. O. and Yuliati, L. (2012). A urea precursor to synthesize carbon nitride with mesoporosity for enhanced activity in the photocatalytic removal of phenol. Chemistry-An Asian Journal, 7: $2139-2144$.

26. Cheng, S-L. and Chen, M-F. (2012). Fabrication, characterization, and kinetic study of vertical singlecrystalline $\mathrm{CuO}$ nanowires on $\mathrm{Si}$ substrates. Nanoscale Research Letters, 7:119 - 126.

27. Zhu, J., Xiao, P., Li, H. and Carabineiro, S. A. C. (2014). Graphitic carbon nitride: synthesis, properties and application in catalysis. Applied Materials \& Interfaces, 6: 16449 - 16465.

28. Dong, G., Zhang, Y., Pan, Q. and Qiu, J. (2014). A fantastic graphitic carbon nitride $\left(\mathrm{g}_{-} \mathrm{C}_{3} \mathrm{~N}_{4}\right)$ material: Electronic structure, photocatalytic and photoelectronic properties. Journal of Photochemistry and Photobiology C: Photochemistry Reviews, 20: 33 - 50.

29. Cui, Y., Tang, Y. and Wang, X. (2015). Template-free synthesis of graphitic carbon nitride hollow spheres for photocatalytic degradation of organic pollutant. Materials Letters, 161: 197-200.

30. Dai, H., Gao, X., Liu, E., Yang, Y., Hou, W., Kang, L. and Fan, J. (2013). Synthesis and characterization of graphitic carbon nitride submicrospheres using microwave method under mild condition. Diamond and Related Materials, 38: 109 - 117.

31. Tiong, P., Lintang, H. O., Endud, S. and Yuliati, L. (2015). Improved interfacial charge transfer and visible light activity of reduced graphene oxide-graphitic carbon nitride photocatalysts. RSC Advances, 5: $94029-$ 94039.

32. Jasman, S. M., Lintang, H. O. and Yuliati, L. (2017). Enhanced detection of nitrite ions over copper acetylacetonate/polymeric carbon nitride composites. Macromolecular Symposia, 371: 84 - 93.

33. Ding, Z., Chen, X., Antonietti, M. and Wang, X. (2011). Synthesis of transition metal-modified carbon nitride polymers for selective hydrocarbon oxidation. ChemSusChem, 4: $274-281$.

34. Luo, J., Cui, Z-C. and Zang, G-K. (2013). Mesoporous metal-containing carbon nitrides for improved photocatalytic activities. Journal of Chemistry, 2013: $1-6$.

35. Mu, T., Huang, J., Liu, Z., Han, B., Li, Z., Wang, Y., Jiang, T. and Gao, H. (2004). Synthesis and characterization of polyester structure carbon nitride. Journal of Material Research, 19(6): 1736 - 1741.

36. Liu, J., Zhang, T., Wang, Z. Dawson, G. Chen, W. (2011). Simple Pyrolysis of Urea into Graphitic Carbon Nitride with Recyclable Adsorption and Photocatalytic Activity. Journal of Materials Chemistry, 21: 14398 14401.

37. Derrien, G., Charnay, C., Zajac, J., Jones, D. J. and Roziere, J. (2008). Copper-containing monodisperse mesoporous silica nanospheres by a smart one-step approach. Chemistry Communication, 27: $3118-3120$.

38. Tang, I. H., Sundari, R., Lintang, H. O. and Yuliati, L. (2016). Polyvinylpyrolidone as a new fluorescent sensor for nitrate ion. Malaysia Journal of Analytical Sciences, 20(2): 288 - 295. 